\title{
The Impact of Oil Subsidy Removal on Infrastructural Development in Nigeria (2000-2012)
}

\author{
Rosemary Anazodo ${ }^{1}$, Uche Ezenwile ${ }^{1} \&$ Chukwurah D. C. $\mathrm{Jr}^{1}$ \\ ${ }^{1}$ School of Management, Nnamdi Azikiwe University Awka, Nigeria \\ Correspondence: Rosemary Anazodo, School of Management, Nnamdi Azikiwe University Awka, Nigeria. Tel: \\ 234-803-348-7395. E-mail: rozyzodos@yahoo.com; ckenec@yahoo.com
}

Received: February 1, 2014 Accepted: March 14, 2014 Online Published: April 29, 2014

doi:10.5539/par.v3n1p88 URL: http://dx.doi.org/10.5539/par.v3n1p88

\begin{abstract}
Nigeria is a country blessed with large quantities of crude oil deposits, but the revenue generated from the oil has added little or nothing to the lives of Nigerians. More worrisome is the fact that the issue of oil subsidy removals by successive administrations has been a matter of controversy, as the proceeds from the removals have not impacted on the development of the country Rather, the bulk of the proceeds fritter away into private pockets, thus leaving the nation in state of decay and total neglect. This paper therefore, tries to examine the impact of oil subsidy removal on infrastructural development in Nigeria. It is therefore recommended that proceeds from subsidy removal should be monitored effectively so as to ensure that they are invested in critical infrastructural development of the country.
\end{abstract}

Keywords: development, infrastructure, subsidy

\section{Introduction}

Nigeria is one of the largest countries in the sub-Saharan Africa. The country is rich both in human and material resources and she is richly blessed especially with crude oil. Nigeria discovered oil in large quantity on the $15^{\text {th }}$ of January, 1956 at Oloibiri in Ogbia Local Government Area of Bayelsa State. After this initial discovery, oil has been discovered in some other states of the country, thereby making Nigeria to pride herself as the $6^{\text {th }}$ largest exporter of oil in OPEC (Balougoun, 2012), Africa's second largest producer of crude oil after Libya, eightieth largest exporter in the whole world (Ovaga, 2012).

Before the discovery of oil, agriculture was the dominate sector of Nigeria's economy. Agriculture provided the foreign exchange that was used in importing raw materials and capital goods. The proportion of GDP accounted by agriculture was $67.0 \%$ and petroleum accounted for $0.6 \%$, with this, the various marketing boards generated much revenue that was used by government to develop the basic infrastructure needed for long term development of the country (CBN Bullion, 2008).

The discovery of oil made Nigeria and Nigerians to divert attention from agriculture to oil. This was evident as crude oil production increased from 1.9 million barrels in 1958 to 152.4 barrels in 1966; from 395.7 million barrels in 1970 to 600.1 and 845.5 million barrels in 1975 and 1979 respectively. The output continued to increase from 711.3 million barrels, 742.3 million barrels and 2.15 billion barrels in 1996, 1998 and 2012 respectively (Akinlo, 2012).

Similarly, the National Government expenditure rose from 9 percent in 1962 to 44 percent in 1979 and to over 1000 percent in 2012. This increase in expenditure did not reflect in the growth and development of the critical sectors of the economy like infrastructure, education, health etc. (Hobenu, 2010).

Admittedly, Nigeria government constructed four refineries to refine petroleum products for local use, but due to lack of maintenance, these refineries produced below the installed capacity (Ezenwile, 2012), thereby making Nigeria the only OPEC country that sends her crude oil abroad for processing and then imports same. Thus, Nigeria is the only country that lacks the capacity to refine her products. In the case of Venezuela, the country has made so much progress that she not only refines her crude oil but also owns petrol and gas stations across the United States of America. (Kujenya, 2011). In corroborating with the non functional refineries in Nigeria, Nelson (2009) observed that Nigeria is the only oil producing country globally that does not have a functional refinery, having had its four refineries not functional due to the deliberate action of those in authority. From financial 
statistics generated, building a refinery is about $\$ 66$ billion USD investment and can be completed within 2 years -from design to completion. Due to the breakdown of refineries, Nigeria was forced to import the products. With the increasing cost of exchange rate, coupled with high freight rate and other logistics involved in the importation of petroleum products, the prices of petroleum products continue to increase. In order to maintain a price that could be affordable by Nigerians, government introduced subsidy on petroleum products. However, the value of subsidy had gone up from $\$ 8$ billion in 1980s to N3.5 trillion in the last five years (PPPRA, 2012).

Based on the huge sum spent on subsidy of petroleum products, successive administrations had made efforts to remove it and the proceeds invested in critical infrastructures that are in bad

conditions. Infrastructure is a key element in the generation of economic growth and the main driver of urban activities (Okenwa, 2002). No wonder that for over 17 times, subsidy had been removed on petroleum products, the target had been to use the proceeds to shore up the ailing infrastructural facilities in the country.

\subsection{The Problem}

Nigeria between 1987-2012 has witnessed series of subsidy removal on petroleum products and successive administrations that embarked on these subsidy removals claim that they would use the proceeds to develop infrastructure, because Nigeria is a country that lacks infrastructural facilities, despite the huge sums that accrued from subsidy removal.

When President Ibrahim Babangida removed subsidy in 1987, he set up Directorate of Food, Road and Rural Infrastructure. He also set up Oil Mineral Producing Area Development Commission, but both failed in their acclaimed responsibilities. It was only General Sani Abacha that succeeded in transferring subsidy removal benefits to Nigerians through the instrumentality of Petroleum Trust Fund. All the promises made by President Olusegun Obasanjo on the use of subsidy proceeds failed to materialize. President Goodluck set up SURE-P to manage the Federal Government's share of the proceeds from subsidy removal, but the programme has not achieved much compared to the fund available to it. (Omokhodion, 2013).

Presently, the National Assembly said that they would not appropriate fund to the programme in 2014 budget because the programme had not justified the fund appropriated to it in 2013 budget.

More worrisome, is the fact that Nigerians still give themselves electricity by resorting to the use of generators; boreholes were dug in the homes, as the government could not provide portable water. Nigerians are securing their lives and properties by engaging local vigilante groups to play the role of security agents. Public Schools are in shambles and dilapidated and so parents send their children and wards to private schools, the roads are death traps to motorists and other road users. Inspite of the rate of degradation of infrastructures, Nigerian government reels in profligate and expensive lifestyle to the detriment of those that they govern.

In view of this, the study seeks to find out how subsidy removals had impacted on the development of infrastructural facilities in Nigeria.

\subsection{Objectives of the Study}

The broad objective of this study is to examine the impact of subsidy removal on infrastructural development in Nigeria while the specific objectives are as follows:

1. To ascertain the extent to which oil revenue has impacted on the development of infrastructural facilities in Nigeria.

2. To compare the infrastructural development of some oil producing countries with what obtains in Nigeria

3. To make recommendations and way forward

\subsection{Significance of the Study}

This study is significant in the following ways;

1. It would be used as a tool for analyzing the lack of infrastructural facilities vis-à-vis the high revenue generated from oil.

2. It would be used by students, academics, institutions and individuals who may want to know about the oil subsidy and its impact on infrastructural development

3. It would form an expository analysis for academic research students and analysts in the continuous underdevelopment of infrastructural facilities in the country and by extension the underdevelopment of the country in general 


\subsection{Theoretical Framework}

The functional superiority of theory as a guide in all fields of human endeavor lies on the fact that rather than base action on judgment derived from mere experiences, guess works or speculations, theories enable a chosen live of action to be anchored in and guided by evidence derived from scientific research which makes the consequences of such an action fall as close in line with the intended direction as possible (Onah, 2003). Based on this, the work was guided by elite theory.

Elite theory was used in the $19^{\text {th }}$ century in Europe and America by notable writers like Michales, Mosca, Burham, Pareto, Gasset, Mills etc however; it was popularized by Gaetona Mosca and Vilfredo Pareto two Italian thinkers (Olsen, 1970). Elite theory is a theory of the state which seeks to describe and explain the power relationships in contemporary society. The theory posits that a small minority, consisting of members of the economic elite and policy-planning networks hold most power and that this power is independent of state's democratic election process.

Furthermore, elite theory refers to those minority actors that exercise influence over public outputs by virtue of their exceptional access to political information and positions, their powers are based on their personal economic resources and especially on their positions within the top management of the big corporation (Patternson, 2009). Thus, their influence and power are geared towards expanding their economic base and that of their cronies.

For instance, it is believed that successive governments in Nigeria have virtually turned the Turn Around Maintenance into a cash cow for close associates and massive drain pipes to the detriment of the larger Nigerian populace. During the Abacha's era, the TAM was said to have been awarded to a particular business man from the East at a cost of $\$ 100$ million (Kanu, 2011). Gen. Abdusalami Abubakar's administration set aside $\$ 92$ million for the rehabilitation of refineries without achieving results. Former President Olusegun Obasanjo frittered about $\$ 350$ million on rehabilitation of refineries and pipeline without success. Late president Yar'Adua doled out about \$54 million on TAM of Kaduna refinery, yet the refinery still produces at below installed capacity.

More importantly, the issue of introduction of subsidy or removal in Nigeria is a function of a group of people who want to further their selfish interest to the detriment of the masses. Since 1987, the argument about deregulating the downstream sector of the petroleum industry has been enmeshed in deceits and subterfuge by the ruling elites (Odiogor, 2012).

\section{Literature Review}

Subsidy, according to Hornby (2005) is seen as money that is paid by a government or an organization to reduce the cost of producing goods and services so that their prices can be kept low. Furthermore, Ovaga (2010) stated that it is a device employed by government to assist either the consumer or producer to consume or produce certain commodities at prices below the prevailing market price.

Iyobhebhe (2012) argued that subsidy is a form of price manipulation where the government fixes the pump price for sale of consumers and pay the retailer the different between the actual market price and the regulated or official price per liter. Subsidy therefore, is the reduction of the price of a particular product so that it can be within the reach of the masses.

Ademikinju (2012), argued that subsidy in Nigeria has resulted in substantial loss of revenue and exponential growth in domestic oil consumption as low price does not signal real cost of consumption. Therefore, oil subsidy has moved from being an implicit subsidy to explicit cost.

Oil subsidy in Nigeria is the difference between the actual cost used in refining the oil abroad and the landing cost. This is always determined by a lot of factors like exchange rate, freight rate, demurrage, transportation and over invoicing by the importers. So what Nigerian government pays as subsidy is not subsidy in its real sense, but money meant to enrich a very small group who has decided to hold the country to ransom because the refineries are not working. In otherwords, Nigerian government is subsidizing corruption and inefficiency occasioned by their lack of commitment to the cause of development of critical infrastructural facilities.

\subsection{Oil Revenue and Infrastructural Development}

Nigeria is a country endowed with significant energy resources. The oil reserves stood at 36 billion barrels, gas reserve stood at 187 trillion cubic feet while oil production stood at 2.016 Mbd (Ademikinju, 2012). Nigeria oil attracts very huge buyers in the international market because the oil is of high quality light sweet crude with low surphur contents of $0.05 \%$ to $0.2 \%$. Below is the table estimated crude oil production and revenue in Nigeria, 2000-2012. 
Table 1. Crude Oil production and revenue in Nigeria, 2000-2012

\begin{tabular}{ccc}
\hline Year & Production million brand & Revenue HM \\
\hline 2000 & 828 & 134,000 \\
2001 & 860 & $1,707,600$ \\
2002 & 726 & $1,236,900$ \\
2003 & 844 & 2074300 \\
2004 & 900 & $3,354,800$ \\
2005 & 923 & $4,762,400$ \\
2006 & 914 & $6,109,000$ \\
2007 & 880 & $6,700,000$ \\
2010 & 2.05 & N/A \\
2011 & 2.13 & N/A \\
2012 & 2.15 & 14.8 trillion \\
\hline
\end{tabular}

Source: Petroleum Inspectorate, NNPC and CBN Annual Report and Statement of Account. NOTE: NA - Not Available

From the table above, it is evident that Nigeria has generated substantial revenue from oil, apart from the few period of oil doom, Nigerian oil has continued to generate revenue for the country.

\subsection{Comparative Analysis}

There is no gainsaying the fact that Nigeria has not used the massive resources endowed on her by nature, for the overall development of the country. This is most evident when you place Nigeria side by side with other oil producing countries of the world. For instance, countries like Saudi Arabia, Kuwait, Qatar, United Arab Emirate, Bahrain, Oman etc have performed very well by investing oil proceeds to create sustainable economic development of their countries. Even some oil producing African countries that have smaller quantity of oil than Nigeria have better per capita GDP when compared with Nigeria. Below is a table of key data on oil production in selected African countries.

Table 2. Key data on oil production in selected African countries

\begin{tabular}{|c|c|c|c|c|c|c|c|c|c|c|}
\hline \multirow[t]{2}{*}{ Country } & \multirow{2}{*}{$\begin{array}{l}\text { Population } \\
\text { million } \\
2003\end{array}$} & \multirow{2}{*}{$\begin{array}{c}\text { Per capita } \\
\text { GDP } \\
2003\end{array}$} & \multirow{2}{*}{$\begin{array}{c}\text { Beginning } \\
\text { of oil } \\
\text { production }\end{array}$} & \multirow{2}{*}{$\begin{array}{c}\text { Barrel of } \\
\text { oil per } \\
\text { capita } 2003\end{array}$} & \multicolumn{3}{|c|}{$\begin{array}{l}\text { Oil production } 1,000 \text { barrel } \\
\text { day }\end{array}$} & \multicolumn{3}{|c|}{ Share (per cent) of oil production } \\
\hline & & & & & 2001 & 2005 & 2015 & $\begin{array}{c}\text { GDP } \\
2001 / 2002\end{array}$ & $\begin{array}{c}\text { Budget } \\
2001 / 2002\end{array}$ & $\begin{array}{l}\text { Export } \\
2001 / 02\end{array}$ \\
\hline Nigeria & 124.0 & 471 & 1963 & 7.1 & 3,083 & 2,179 & 3,729 & 40 & 70 & 92 \\
\hline Angola & 13.6 & 1015 & 1956 & 24.0 & 740 & 1,098 & 2,549 & 54 & 85 & 89 \\
\hline Equatorial Guinea & 0.5 & 6026 & 1992 & 197.3 & 195 & 400 & 653 & & 82 & 77 \\
\hline Sudan & 33.6 & 529 & 1992 & 2.7 & 230 & 310 & & & & \\
\hline Re. of Congo & 3.7 & 957 & 1957 & 24.7 & 273 & 285 & 314 & 39 & 68 & 92 \\
\hline Gabon & 1.3 & 4566 & 1961 & 73.5 & 259 & 250 & 100 & 41 & 64 & 81 \\
\hline Chad & 8.6 & 307 & 2004 & & 0 & 230 & 80 & & & 0 \\
\hline Cameroun & 16.0 & 862 & 1978 & 73.5 & 107 & 84 & 66 & & & 43 \\
\hline DR Congo & 52.8 & 108 & & 1.6 & 24 & 30 & 30 & & & \\
\hline Cote d'Ivoire & 16.6 & 845 & & & 12 & 43 & 83 & & & 13 \\
\hline $\begin{array}{c}\text { Sao Tome and } \\
\text { Principe }\end{array}$ & 0.2 & 370 & 2005 & 1.2 & 0 & 0 & 150 & & & 0 \\
\hline
\end{tabular}

Source: African Development Bank and Development Centre of the Organization and Economic Co-operation development (OECD) (2005) 
The table above showed that Nigeria had \$471 GDP, whereas Equatorial Guinea and Angola had \$6026 and 1015 respectively. Although, Nigerian GDP super passed countries like Chad and DR Congo.

In terms of electricity profiles of countries, Nigeria has one of the least megawatts in the world.

Table 3. Electricity profiles in Nigeria and other countries (2001-2008)

\begin{tabular}{cccccc}
\hline Countries & $\begin{array}{c}\text { Population } \\
\text { million }\end{array}$ & $\begin{array}{c}\text { Capacity } \\
(\mathrm{mw})\end{array}$ & $\begin{array}{c}\text { Per capita power capacity } \\
\text { watts/ person }\end{array}$ & $\begin{array}{c}\text { per capital consumption } \\
\text { kwh/yr }\end{array}$ & $\begin{array}{c}\text { GDP } \\
\text { billion of } \$\end{array}$ \\
\hline USA & 297.6 & 848,300 & $2,889.30$ & $12,465.94$ & 11,750 \\
Germany & 82.6 & 115,000 & $1,392.25$ & $6,209.40$ & 2,362 \\
UK & 59.7 & 76,300 & $1,265.90$ & 5,742 & 1,782 \\
S. Africa & 42.7 & 44,650 & $1,046.70$ & 4.243 .60 & 491.40 \\
Brazil & 179.1 & 86,020 & 480.30 & - & 1,492 \\
China & 1,300 & 338,300 & 260.00 & $1,120.30$ & 7,262 \\
India & 1,086 & 115,520 & 106.31 & 582.00 & 3,319 \\
Ghana & 20.7 & 1,762 & 85.12 & 334 & 48.27 \\
Nigeria & 140 & 4000 & 29.133 & - & 125.70 \\
\hline
\end{tabular}

Source; Adapted from Nnaji (2008) P. 216.

From the table above, Nigeria could only generate 400 mega watts of electricity for a population of 140 million people with per capita power capacity watt per person of 29.133 . This is quite poor when you compared with a country like United States of America that generates 848,300 mega watts and per capita power capacity watts per person of 2,889.30.

\subsection{Oil Subsidy Removal and Its Impact on Infrastructural Development}

Subsidy on oil was first removed in 1987 by the former military General Ibrahim Babangida, when the four refineries of the nation could only produce little which was not enough to satisfy the domestic needs of the people. Then, a need arose for the importation of finished petroleum products such as diesel, petrol and kerosene to meet the domestic needs of Nigeria.

In order to cushion the effects of the high cost of importation occasioned by high exchange rates and other logistics, government subsidized the prices of petroleum products. When it became imperative that the high cost of subsidy was eating deep into the coffers of the nation, government decided to remove it, and its proceeds used to develop infrastructural facilities. Below is the table that shows various subsidy removals.

Table 4. Subsidy Removal from 2000-2012

\begin{tabular}{ccccc}
\hline s/n & Date & Administration & Price & percentage \\
\hline 1 & 2000 & Obasanjo & $\$ 20.00$ & $82 \%$ \\
2 & 2000 & Obasanjo & $\$ 22.00$ & $10 \%$ \\
3 & 2001 & Obasanjo & $\$ 26.00$ & $18 \%$ \\
4 & 2003 & Obasanjo & $\$ 40.00$ & $54 \%$ \\
5 & 2004 & Obasanjo & $\$ 45.00$ & $13 \%$ \\
6 & 2007 & Obasanjo & $\$ 70.00$ & $56 \%$ \\
7 & 2007 & Yar'Adua & $\$ 65.00$ & $0.07 \%$ \\
8 & 2012 & Jonathan & $\$ 141.00$ & $117 \%$ \\
9 & 2012 & Jonathan & $\$ 97.00$ & \\
\hline
\end{tabular}

Source: Communiqué by South-South Elders and Leaders 
The table above showed that President Obasanjo removed subsidy on petrol for six times, President Yar'Adua reduced it to N65 because of pressure from Labour Organizations while President Jonathan shot it up to N141, when the pressure became much he reduced it to N97.

\section{Findings}

The researchers found out the following;

1. That the Nigeria's huge oil revenue has not impacted on the development of infrastructural facilities in particular and the overall development of Nigeria in general.

2. That Nigeria's infrastructural development is at its lowest ebb when compared with other oil producing countries

3. That the various subsidy removals have not impacted on the development of infrastructural development of the country.

\section{Discussions}

Nigeria is ranked the $6^{\text {th }}$ largest producer of oil in the OPEC, and the $8^{\text {th }}$ exporter of oil. This exportation no doubt, generated substantial revenue for Nigeria, but this revenue has not been translated into quality of lives for Nigerians and better infrastructural development (Falola, 2008), as the country did not make the list of 11 countries in Sub-Saharan African that recorded more than two percent annual gains since 2000 (HDI, 2013). More worrisome is the fact that the country's Human Development Ranking had continued to dwindle from 142 out of 163 countries in 2010 to 153 out of 186 countries of the world in 2013. More importantly Nigeria's economy also ranks in the bottom when compared to its oil producing peers (Folola, 2008). Worthy of mention is the fact that by 2000 , oil and gas exports accounted for more than $98 \%$ of export earnings and about $83 \%$ federal government revenue. Yet, Nigeria is a poor country based on the GDP per head of population. The 2012 Global Finance ranking of the richest/ poorest countries of the world placed Nigeria as the $43^{\text {rd }}$ poorest nation in the world with a GDP purchasing power parity per head of \$2.358, and with infrastructural gap of $\$ 32$ trillion (Nwachukwu, 2012).

Again in the 1970s and 1980s, Nigeria's economy experience a rapid growth of about 8 percent per year that made Nigeria, by 1980, the largest economy in Africa. Instead of use these revenues for the development of the country, successive administrations became father Christmas by splashing money on every African country that had the slightest problem. They embarked on ventures like FASTAC 77, formation of ECOWAS and frivolous monetary donations to African countries in particular and other countries of the world in general. All these activities plunged the country back into economic crises, that by 1993, the external loan of Nigeria had escalated to US\$ 30 billion.

Furthermore, the corruption in NNPC, the continuous pipeline vandalization, the incessant oil theft and over invoicing of the elitist class have further whittled down the revenue profile of the country. Again the expensive life style of those in government has further diminished the revenue of the country. For instance, in 2012 budget, the Presidency alone had a feeding allowance of $\$ 1$ billion, over $\$ 1$ billion was budgeted for medical treatment in Aso rock clinic; over N1 billion budgeted for fuel and generating sets, and N300 million was for dining sets. The least security vote allocated to governors was N6 billion a year while a Nigerian Senator earns about N245 million per annum, representing the salaries of about 25 Vice Chancellors or 50 Medical Doctors or 60 Directors in public service or 500 school teachers. (Adejuwon, 2012).

\subsection{Nigeria and Other Oil Producing Countries}

Nigeria is a country where the oil revenue has not impacted on the lives and infrastructural development of the country, when compared with other rich oil producing nations. For example, Nigeria discovered oil the same time with United Arab Emirate. But rather than waste their resource, UAE embarked on resource-based- industries (RBI) as a development strategy. They deployed their windfall income into a once-and-for-all boost to the social and economic infrastructure, which enabled the UAE to achieve a significant degree of economic development within a very brief time frame. Today, aside from the fact that the country's income level can be compared with other industrialized nations, their educational, social and health infrastructures are of world class standards (Ministry of Planning, UAE, 1990).

Saudi Arabia, another oil producing country is one of the world's most important oil-based economies. Saudi Arabia embarked on one of the most ambitious efforts ever, to diversify and modernize their economy. These efforts have touched virtually every aspect of the Saudi economy to the extent that Saudi has improved from $67^{\text {th }}$ to $13^{\text {th }}$ on the ease of doing business scale published by the world bank. The kingdom's accession to the World Trade Organization is attributed to the developing and improving infrastructure at every level, and ensuring that new infrastructure is add to accommodate the rapid changes in the Saudi economy and society, especially given the significant recent and projected future increase in population. 
Angola is an African oil producing country, although its volume of output is not as huge as Nigeria's export but the revenue generated from their oil has been put into the development of infrastructural facilities. In 2010 Angola cut its oil subsidy and by 2014 a new refinery will be commissioned in the Port City of Lobito, work has reached an advanced stage as government was committed to its completion (www.theeconomyng.com).

Furthermore, inspite of the volume of revenue generated from oil, Nigeria is ranked 37 out of 56 countries in the continent in terms of GDP and infrastructural development.

\subsection{Oil Subsidy Removal and Its Impact on Infrastructural Development in Nigeria}

During President Obasanjo's regime, Nigeria witnessed series of oil subsidy removal, but the proceeds from these subsidies did not impact on the infrastructural development of the country. This was evident as the educational system, health care facilities and road networks were not improved upon, despite the promise made by his administration to invest subsidy proceeds in infrastructural development. However, part of the reason why these were not done was largely due to the existence of oil cabals that fritter subsidy money into their private pockets.

No wonder, Onanuga (2011), observed that since the inception of oil subsidy removal, government arithmetic in the subject, as in all other subjects, has never really agreed with that of its agencies nor has oil transactions been transparent. Moreso, the government has agreed that a 'cabal' is defrauding her of the so called subsidy. In addition to having conflicting statistics, the government had subjected ordinary Nigerians to undeserved punishment, rather than square-up with the members of the oil cabal that have profited immensely from the so called oil subsidy removals.

Burning with the zeal to stop these cabals from feasting fat on the masses, President Yar'Adua challenged their nefarious activities when his Special Adviser on Media Mr. Segun Adeniyi observed as follows:

"As we all know, what government is trying to do is to question the rationale behind the subsidy in the first place. What and who are we subsidizing? As the Minister of Finance observed that, we are subsidizing corruption, inefficiency and fraud in the oil sector. From the look of things, these cabals have held the country to a stand still; they have billed Nigerians many times over their actual expenses and pad their invoices with scandalous margin of profit and Nigeria will pay as long as it remains our only means of survival".

From the look of things, it was clear that the oil subsidy removal in Nigeria was faulty abinitio, as such the proceeds can never be used for the development of infrastructural facilities, rather it will be used to feather the nest of the elites. Utomi in Odiogor (2012) corroborated this point when he said that;

"What Nigerians have witnessed on the downstream sector or removal of the local subsidy as enthroned by the petroleum equalization fund is nothing but periodic petrol tax and manipulation of the process of petroleum products by the ruling elites that have found a way of taxing Nigerians to be able to sustain their luxury and comforts".

President Goodluck Jonathan in 2012 removed subsidy on petrol, he promised among other things to invest the proceeds in tangible infrastructures and provision of safety nets that would have direct impact on the masses. The Minister of Petroleum, Mrs. Diezani Madueke collaborated what the President said when she informed Nigerians that the proceeds would be invested in the construction of Abuja-Abaji-Lokoja dual carriage way and Kano-Maiduguri dual carriage way. Some others included Oweto Bridge in Benue State, second Niger Bridge, East-west road, Port Harcourt-Ahaoda road and Ahaoda-Kaiama road (Obasi, 2012).

To achieve this, the Federal Government set up Subsidy Reinvestment Empowerment Programme (SURE-P), aimed at mitigating the immediate impact of the removal of fuel subsidy and accelerate economic growth through investment in critical infrastructure (Nweje, 2013).

The programme was mandated to invest subsidy proceeds in infrastructural facilities, so as to speedily meet up with the infrastructural needs of the country. It must be noted that the Federal Government makes an annual budget for power, roads, health, education, security, transportation, agriculture etc and these are the same sectors where it intends to utilize the saved subsidy fund. Nevertheless, barely two year after the inauguration of SURE-P, there has not been any meaningful improvement in the state of infrastructural facilities in the country. (Nweje, 2013). This point was supported by Anya (2013) when he observed that the turn around maintenance of Port Harcourt refinery scheduled for the first quarter of 2012 has not begun. The construction of eight new major roads, two bridges, six rail ways, 19 irrigations, health care centres for three million pregnant women are yet to commence. More disturbing is the fact that $\$ 500$, billion SURE- P fund is missing and agencies are trading blames on each other over the missing fund (Azimazi, 2013). More importantly, the oil cabals, some oil marketers and cronies of those 
in government have further emasculated the main essence of oil subsidy, as they engaged in variety of means to over charge the Nigerian government for subsidy payments. Apart from this, the expensive life style of those in government has further diminished the proceeds from subsidy removal to the detriment of infrastructural development.

From the look of things, it is clear that the pogramme has failed, as it could not solve the infrastructural problems of the country. The funds that would have been used to transform the country are missing, and those in authority are treating the matter with every carefree attitude while the country's roads, healthcare systems, educational system, refineries etc are in shambles. More disheartening is the fact that the lecturers of Public Universities went on strike for about four months over infrastructural challenges of the country's universities. While the leaders of the country are busy buying bullet proof cars and luxuriating in mindless affluence. No wonder, Achebe (2012) observed that if the present government reduces its bloated budget and curbs the outrageous salaries of parliamentarians, state governors and local government's officials. It could yield an additional hundred, if not billions of dollars a year that would be invested in infrastructural development of the country.

\section{Conclusion}

Nigeria had over the years made huge profits from petroleum products and removal of subsidy, but little or nothing was done to invest these proceeds into critical infrastructures that would better the lives of Nigerians. Sadly, these masses are left to suffer as most of the infrastructural facilities are in comatose, despite the promises made by Nigerian leaders to invest proceeds of subsidy removal into infrastructural facilities.

We therefore conclude:

a. That the proceeds on subsidy removals has very little or no impact on the development of infrastructural facilities in Nigeria.

b. That Nigeria has the least infrastructural development when compared with other OPEC

c. That the huge oil revenue generated by the Federal Government has little impact on the development of infrastructural facilities in Nigeria.

\subsection{Recommendations}

The researchers recommend the following as ways of ensuring that proceeds from subsidy removal impacted on the infrastructural development.

1. Proceeds from the removal of subsidy on petroleum products should be monitored so as to ensure that they are invested in critical infrastructures

2. Funds generated from oil subsidy removal should be managed by the Accountant General of the Federation and not NNPC or its subsidiaries. This fund should be supervised by credible financial consultants so as to ensure due process in its distribution.

3. That Government should construct new/modern refineries and the old ones sold out to private individuals. This will allow for healthy competition between public owned and private owned refineries.

4. The Federal Government should be sincere in enthroning governance infrastructure, so as to enable them break the excesses of the so called cabals in the oil sectors.

5. The Petroleum Industry Bill should be passed into law as quickly as possible

6. The institutions that tackle corruption should be strengthened so as to curb corruption in the petroleum industry.

\section{References}

Achebe, C. (2012). Government should reduce its bloated budget. Newswatch, January 23.

Adejuwon, S. (2012). Tackling the Subsidy Mess. Tell, January 16.

Adekeye, F. (2008). The nightmare worsens. Tell, February 11.

Adekeye, F. (2009). A covenant with Darkness. Tell, July 27.

Ademikinju, A. (2012). Energy pricing and subsidy reforms in Nigeria. A paper presented at the African Development Bank and Development Centre of the Organization and Economic co-operation Development (OECD).

Ajanaku, L. (2008). The squandering of Riches. Tell, February 18.

Akabueze, A. (2011). Culture of Neglect. Newswatch, June 6. 
Akinlo, A. E. (2012). How Important is oil in Economic Growth. Journal of Sustainable Development, 5(4), 165-179.

Anya, V. E. (2013). Where are the gains from the removal of subsidy? Daily Independent, February 1.

Asimi, T. (2005). Factors in Nigeria's oil Problem. Nigerian Tribune, January 13.

Azimazi, M. J., \& Meya, E. (2013). N500b SURE-P funds missing, says Senate. The Guardian, November 6.

Balogoun, J. (2012). The Political Economy of Oil Subsidy in Nigeria (Second quarter, pp. 31-35). International Association for Energy Economics.

Bullion Publication of CBN. (2008, April-June). 32(2).

Cannor, K., \& Sander, S. (2010). Building for the future- an overview of infrastructural development tin the Kingdom of Saudi Arabia: Middle East and Africa Global reference Guide on Infrastructure (pp. 24-25).

Communique by South-South Elders and Leaders. (2012). Tell, January 16.

Emejor, C. (2013). Deplorable conditions of Nigerian road. Daily Independent, January 17.

Ezenwile, U. (2012). The Impact of Maintenance Culture on Public Infrastructural Facilities in Anambra State. (M.Sc. Thesis). Department of Public Administration, Anambra State University.

Falola, T., \& Heaton, M. (2008). A history of Nigeria. London: Cambridge University Press.

Hobenu, T. (2010). Optimizing the use of revenue from Ghana's oil fields-Case for Oil funds. Journal of Business and Estate Management Research (JBEMR), 2(1), 47-67.

Hornby, A. S. (2005). Oxford Advanced learners Dictionary (International Students' Edition). New York: Oxford University Press.

Kanu, D. (2011). United Again fuel subsidy removal. Daily Independent, October 12.

Kujenya, J. (2011). Nigeria Lacks capacity to create values from Petroleum. The Nation 18/10/2011.

MOP (Ministry of Planning, UAE) economy and Social Indictors in the UAE 1975-1990.

Nelson, E. (2009). Everybody say no to deregulation. Tell, November 30.

Nnaji, B. (2008). Challenges of Power in Nigeria: Issues in Projects selection, risk, financing and operation. Paper presented at the African Infrastructure Summit, Pretoria, South Africa, October, 7.

Nwachukwu, E. (2012). Fuel Subsidy: Examining the facts. Punch, January 13.

Nweje, C. (2013). The man, Dr. Christopher Kolade. Daily Independent, January 17.

Obasi, S. (2012). Oiling the Guns. Newswatch, January 16.

Odiogor, H. (2012), The Issue of subsidy. Vanguard, January 11.

Okenwa, G. E. (2002). Planning Development and Maintenance of Infrastructures and Growth of the National Economy. Enugu: Snapp Press Ltd.

Olsen, E. M. (1970). Power in Societies. London: Macmillan Press.

Omokhodion, L. A. (2011). The Inside story of Petroleum Subsidy Saga. Thisday Live, October 30. P. 54.

Onah, I. O. (2003). Human Resource Management. Enugu: Fullade Publishing Company.

Onanuga, A. (2011). Subsidy battle in Lagos: Labour Government forces clash at Town Hall meeting. The Nation, December 23.

Ovaga, O. H. (2012). Subsidy in the Downstream Oil Sector and the fate of the masses in Nigeria. Kuwait chapter of Arabian. Journal of Business and Management Review, 1(6), 15-34.

Patterson, T. E. (2009). The American Democracy (9th ed.). New York: McGraw-Hill.

Uffot, E. (2011). Healing or killing centers. Newswatch, June 6.

UNDP (United Nations Development Program) Human Development Report (1999). Oxford University press.

Wurthnam, G. (2006). Ways of using the African oil boom for Sustainable Development. African Development Bank Economic Research Working paper series, (84), 401-405. 


\section{Copyrights}

Copyright for this article is retained by the author(s), with first publication rights granted to the journal.

This is an open-access article distributed under the terms and conditions of the Creative Commons Attribution license (http://creativecommons.org/licenses/by/3.0/). 